\title{
RECHARGING THE GROUND WATER IN EAGLE VALLEY, WEST-CENTRAL NEVADA, BY AUGMENTING NATURAL STREAMFLOW IN VICEE CANYON
}

\section{TIIE PROBLFA}

Eagle Valley is a small basin on the eastern flank of the Slerra Nevada range, about $30 \mathrm{miles}$ south of Reno. The valley encompasses Carson City, the capital of Nevada. Ground water from Eagle Valley is a major source of water supply for the City.

The population of Carson City has grown from about 5,000 in 1955 to about 36,000 in 1987 . Increased ground-water pumping to meet the population needs has caused the water table on the west side of Eagle Valley to decline as much as 50 feet since 1972. As a result, some wells have gone dry and there is concern that the existing water supply will not be adequate for the future population.

\section{A ROSSIBLE SOLUTION}

Vicee Canyon begins in granitic bedrock of the Carson Range and extends eastward through the upper part of an alluvial fan on the northwest side of Eagle Valley. (An alluvial fan is a deposit of sediments formed by streams at the base of a mountain range.) During the past million years, streamflow eroded the alluvial fan and produced the canyon which today ranges from 40 to 700 feet wide and as much as 100 feet deep. A stream, fed largely by runoff from the Carson Range, now meanders across the flat canyon floor at an average flow rate of 1 to 2 cublc feet per second. Except during periods of high streamflow, most of the water percolates through the canyon floor to become ground water.

In February 1982, a major flood with an estimated flow rate exceeding 50 cubic feet per second deposited a wide, thick layer of sand and gravel on the floor of vicee Canyon upstream from a city water-supply well.

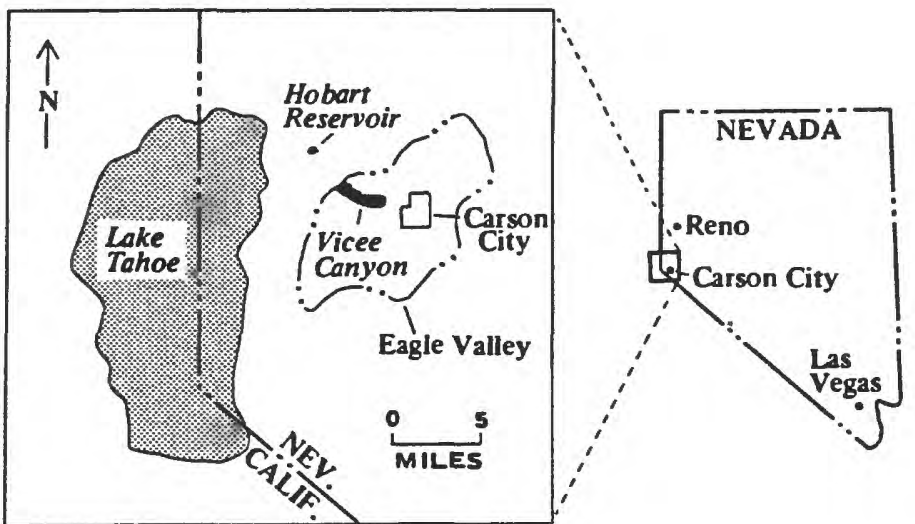

This fresh deposit formed a natural infiltration bed and allowed substantial quantities of streamflow to percolate Into the ground water.

The Carson City Public Works Department speculated that this source of recharge might be increased by augmenting the natural streamflow in Vicee Canyon during periods of low flow. An existing pipeline, which transmits water from Hobart Reservoir in the Carson Range northwest of Eagle Valley to storage tanks near Vicee Canyon, could be used to supply additional water to the canyon. As a result, the Public Works Department asked the U.S. Geological Survey (USGS) to study the feasibility of using augmented streamflow for long-term recharge to the ground water, to estimate how much the flow would add to the ground-water resource. and to assess how this added flow would affect the natural stream channel.

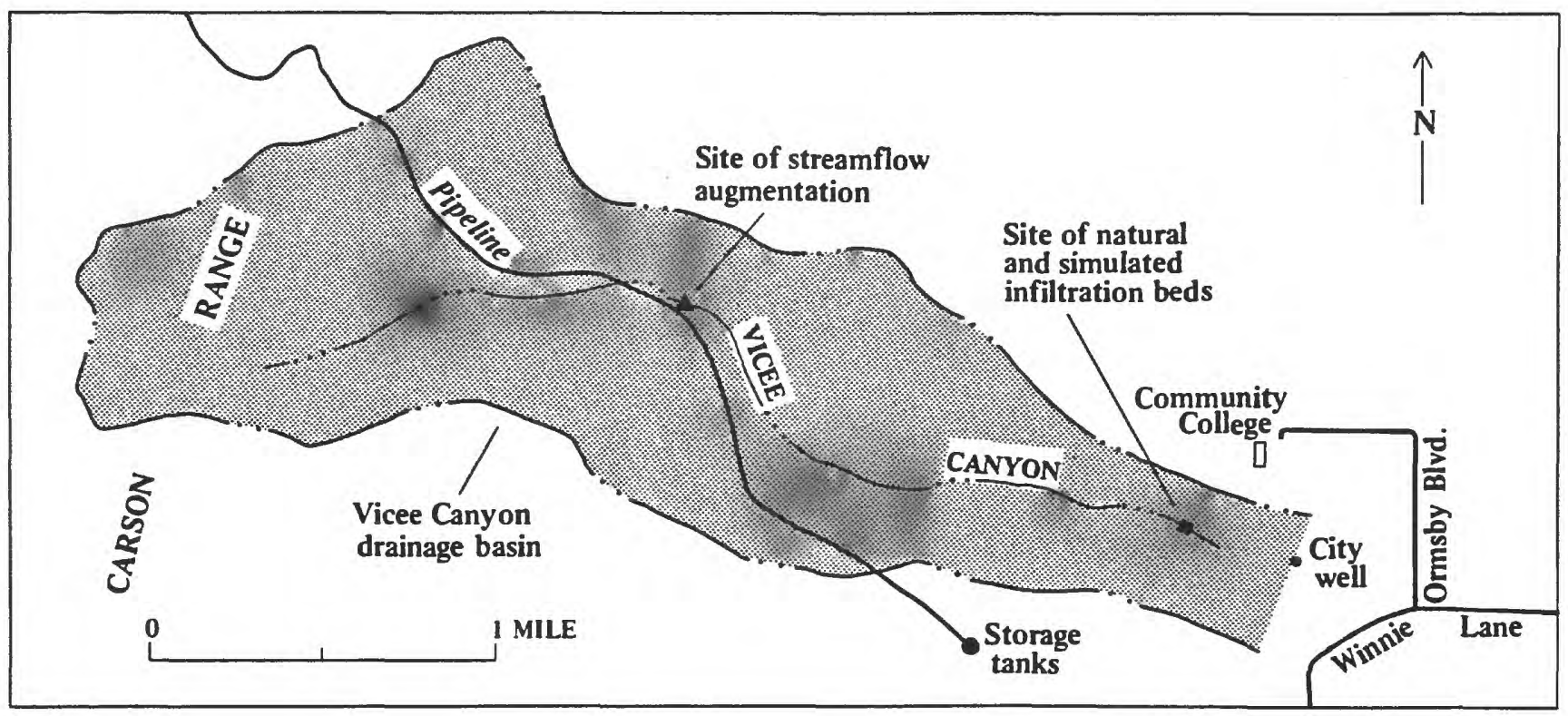


THE STUDY

The USGS began the study in 1983 with the placement of hydrologic instruments at strategic points to collect a broad spectrum of data. Streamflow gages were installed to measure flow in the canyon, instruments that measure percolation rates were burled beneath the streambed, and measurements of changes in the stream channel on the canyon floor were begun. Several new observation wells were drilled, and waterlevel measurements were made perlodically in both the new and nearby existing wells. The Hobart Reservoir pipeline was tapped in 1984, and four augmentation tests were made by releasing water into the canyon.

Data were collected through 1985; then the Interpretation began. A simple mathematical computer model was developed to simulate the hydrologic properties of the sediments beneath Vicee Canyon and the response of ground-water to augmented streamflow.

Record amounts of rain and snow in 1983 caused flow rates that were 2 to 3 cublc feet per second above normal in the canyon, providing en example of how augmented streamflow would affect the stream course and the infiltration bed that had been produced by the 1982 flood. The high flows gradually eroded a channel through the infiltration bed. Eventually, all flow was channeled into this narrow stream course, thereby decreasing the area over which infiltration had been taking place and reducing the quantity of recharge to the ground water.

\section{TIIE RESULTS}

The hydrologic data collected during the study indicated that the floor of vicee Canyon is conducive to artificial recharge by infiltration of augmented streamflow. However, the high flows that destroyed the natural infiltration bed demonstrated that a naturally produced bed is not a rellable solution for long-tetm, year-round recharge. An alternative to using a naturally produced bed would be to construct a per. manent infiltration bed. Therefore, the computer model was used to simulate a permanent bed, with dimensions of 100-by-100 feet, on the floor of the canyon. The model indicated that, at present pumping rates, water levels beneath Vicee Canyon and at a nearby city well could rise as much as 15-30 feet after 5 years in response to about 1 cublc foot per second ( 720 acrefeet per year) of additional streamflow into the infiltration bed.

\section{FURTIUER INFORMATION}

The study described briefly above is discussed in much greater detall in a recently released technical report titled "Recharge to the Eagle Valley GroundWater Basin by Streamflow in Vicee Canyon, West-Central Nevada." The publication, by Douglas K. Maurer and Jeffrey M. Fischer. is USGS Water-Resources Investigations Report $88-4158$. The report $c a n$ be reviewed in Carson City at the offices of the Carson City Public Works Department and the U.S. Geological Survey, and at the Nevade State Library and the Ormsby Public Library. It can be purchased from the U.S. Geological Survey, Books and Open-File Reports Section, Box 25425, Bldg. 810, Federal Center, Denver, CO 80225.

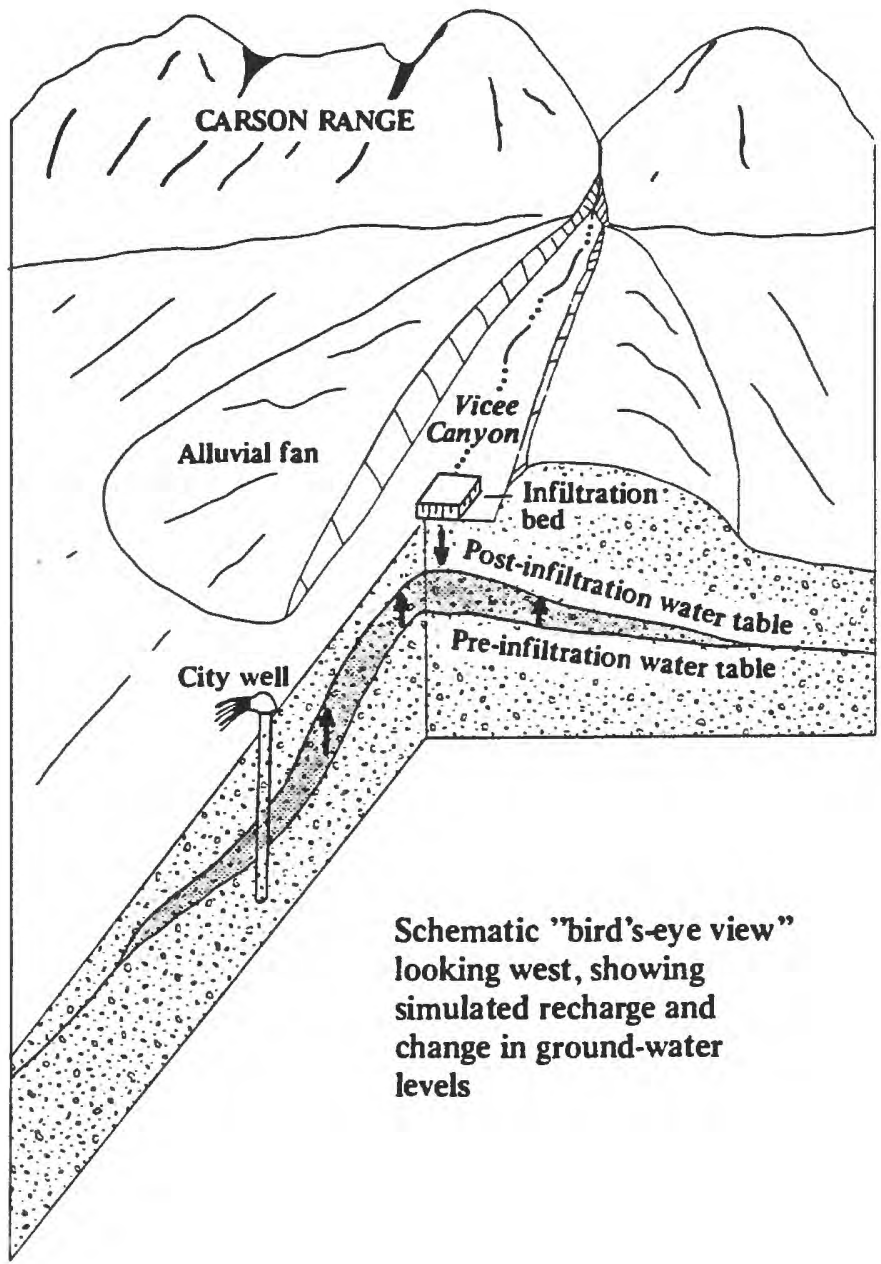

For more information about water resources in Carson Clty, contact:

Carson Clty Public Works Department 2621 Northgate Lane, Suite 59 Carson C1ty, NV 89701

For Information about water-resources investigations throughout Nevada, contact:

District Chief

U.S. Geological Survey

705 North Plaza Street

Carson C1ty, NV 89701 